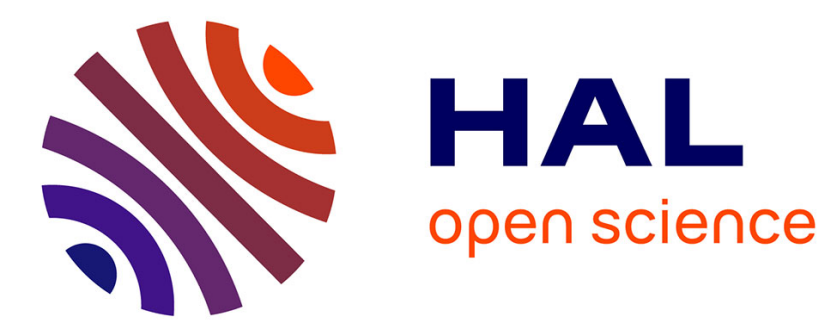

\title{
Urban design and civic spaces: nature at the Parc des Buttes-Chaumont in Paris
}

Ulf Strohmayer

\section{To cite this version:}

Ulf Strohmayer. Urban design and civic spaces: nature at the Parc des Buttes-Chaumont in Paris. cultural geographies, 2006, 13 (4), pp.557-576. 10.1191/1474474006cgj375oa . hal-00572177

\section{HAL Id: hal-00572177 \\ https://hal.science/hal-00572177}

Submitted on 1 Mar 2011

HAL is a multi-disciplinary open access archive for the deposit and dissemination of scientific research documents, whether they are published or not. The documents may come from teaching and research institutions in France or abroad, or from public or private research centers.
L'archive ouverte pluridisciplinaire HAL, est destinée au dépôt et à la diffusion de documents scientifiques de niveau recherche, publiés ou non, émanant des établissements d'enseignement et de recherche français ou étrangers, des laboratoires publics ou privés. 


\title{
Urban design and civic spaces: nature at the Parc des Buttes-Chaumont in Paris
}

\author{
Ulf Strohmayer
}

Department of Geography, National University of Ireland, Galway

\begin{abstract}
Transcending the dualism between 'nature' and 'culture' has been one of the central aims of geographical knowledge during the last decade or so. The present paper adds to this growing body of literature by focusing on the construction of a key space of the French Second Empire (18521870), the Parc des Buttes-Chaumont in the newly created 19th arrondissement in Paris. The paper argues that the nexus between culture and nature - what has been described most fittingly as 'social nature' in the literature - can profitably be approached through the lenses afforded by a reformulated concept of labour. Taking cues from Don Mitchell's conceptual notion of 'dead labour', the paper explores the impact of both technology and design on an emerging urban nature that was to be centrally implicated in the naturalization of many values within an emerging bourgeois, Western world with its emphasis on the commodification of increasing parts of everyday life. Ostensibly non-commodified urban park landscapes were implicated in this process precisely because they embodied a notion of 'labour' that was - and continues to be - both necessary and homogeneous and thus akin to the sense of labour developing in the world of commerce at the same time.
\end{abstract}

' U rban nature' long appeared to be little more than an oxymoron within the popular imagination: cities, after all, were defined by their metaphorical distance from all things natural. Not so any more. The rise of ecological urbanism within architecture, ${ }^{1}$ astute historical analyses of the debt owed to nature by urban planners, ${ }^{2}$ a number of smaller-scale studies by historians, geographers and other spatially minded scholars ${ }^{3}$ and of course seminal studies like John Barrell's The dark side of the landscape and Denis Cosgrove's Social formation and symbolic landscape have all but obliterated what was at best a counterproductive dichotomy. 'Urban' material landscapes now emerge as contested concepts with fluid boundaries, as 'social' or 'produced' nature.' This essay adds to the growing literature by shifting the focus onto the technologies involved in naturalizing a crucial part of the urban landscape, the park. It argues that the process of naturalization involves both original and continuous deployments of labour that never become visible as such. The labour necessary for a park's creation and maintenance, I will argue, is structurally akin to the 'dead labour' theorized successfully by Don Mitchell ${ }^{6}$ - and yet, in the absence of a clearly definable product, it 
may well be apt to talk about 'labour' in a more abstract sense as the condition of possibility for nature to become urban.

In short, the present essay attempts to situate 'labour' at the nexus between wider debates attaching to the materiality of constructed nature. Epistemologically, as David Demeritt has pointed out, the status of that which is constructed, and which thus becomes a reality that is independent from its construction, has plagued discourse since the coining of the term 'social nature'. 7 The notion of 'labour' offers a way forward in that it involves the continuous working of reality in a context that is materially stable at any given point in time while remaining open to future reworkings - and to the inclusion of new forms of materiality. ${ }^{8}$ It is in this precise context that the present paper places the construction of one particular urban space, the Parc des Buttes-Chaumont in the Parisian 19th arrondissement, at the nexus of a host of different discourses: technological, memorializing and moral ones in particular. Its modest aim is to explore how viewing the construction of nature as technologically inspired work may help future analyses of urban natures.

Implicitly, the focus of this essay thus complements the one adopted in Bernard Debarbieux's paper published in the pages of this journal some years ago. ${ }^{9}$ Where Debarbieux's paper focused on the connotations surrounding and actively attributed to a large urban park in Montreal, and thus adopted an implicitly phenomenological approach, the present essay is less concerned with symbolic meanings or even contestations. Instead, it focuses on the conditioning - not determining - aspects of park design that are no less crucial for not being accessible in the form of experiences.

\section{Contextualizing nature in nineteenth-century France}

It was destined to be remembered as yet another splendid day in the annals of Second Empire Paris. With the grand opening of the 1867 World's Fair just hours away, the newly concocted and carved up 19th arrondissement witnessed the inauguration of a park quite unlike any other within the city bounds. It was on the first day of April 1867 that an already sickly Emperor Napoleon III and his wife Eugénie travelled the length of Paris from the Champ de Mars to the heights of Belleville, from the site of that year's Exposition Universelle to the newly created Parc des Buttes-Chaumont, a journey which in many ways was the swansong of the régime. But what a park was awaiting the royal couple at the end of their trip: mountains, waterfalls, restaurants, splendid vistas all added up to what the inaugural guidebook simply called a 'paradise', a 'delicious oasis ... [which] in and of itself would be enough to illustrate a reign'. ${ }^{10}$

In what follows, I shall describe the Parc des Buttes-Chaumont as a historically constructed space that manifests many of the core elements now seen to be characteristic of nineteenth-century French society. However, this manifestation is not a simple and straightforward reflection of otherwise independent social, cultural or political factors; rather, it creates and simultaneously alters the conditions of possibility for these factors to operate. 
The construction of the Buttes-Chaumont was arguably one of the crowning accomplishments of the Second Empire, and as such is an integral component of the transformation of Paris under the authoritarian control of both the Emperor Napoleon III and the Prefect for the Department of the Seine between 1853 and 1869, Baron Georges-Eugène Haussmann. ${ }^{11}$ Since the impact of Haussmann on both the morphology and the social geography of Paris counts among the more profoundly studied episodes in modern history, some brief reminders will suffice for the creation of an initial context. During the 19 years of its existence, the Second Empire transformed its capital from a (largely) medieval city into a modern metropolis, chiefly by facilitating flows of various kinds to improve the circulation of goods, people and capital. This was achieved by broadening avenues into boulevards, constructing new railway stations, tearing down slum quarters and displacing a large segment of the working population of Paris, and through the implementation of modern technologies including gas lighting, sewage works and the realization of mass transport systems. ${ }^{12}$ It was as part of this transformation of Paris that the Parc des Buttes-Chaumont came into being. It was not the only 'green' space to be incorporated into the makeover of the city: both the (existing) Bois de Boulogne and the Bois de Vincennes underwent extensive regenerations during this period, the Parc Monceau in the 17th arrondissement was altered dramatically, and the Parc Montsouris, now adjacent to the RER (light railway) station 'Cité Universitaire', was built from scratch. ${ }^{13}$ Although an integral component of the metamorphosis of Paris between 1851 and 1870, the Parc des Buttes-Chaumont alongside most of the other parks just mentioned - occupied a peripheral position within the French capital. It did so first of all in an obvious sense: the 19th arrondissement, whose heart the Buttes-Chaumont forms to this present day, was only incorporated into the city of Paris proper in 1860, together with eight other newly created arrondissements. Here the workings of Haussmann's capital machine, so aptly described by David Harvey and others, ${ }^{14}$ could not function in quite the same manner as it did in the more centrally located areas of Paris: only state intervention pure and simple - as opposed to a more refined public-private partnership - was capable of transforming a perceived medieval quality of urban life into a more modern form of urban experience. ${ }^{15}$ But the site of the Buttes-Chaumont was peripheral also in more symbolic ways, and it is to these aspects that I shall now turn my attention.

\section{Park histories}

Surveying the history of the construction of the Parc des Buttes-Chaumont, what strikes the contemporary onlooker most is the sheer speed with which the authoritarian regime of Napoleon III transformed this space. The Park was conceived and decreed by Haussmann in 1862, construction began in the spring of 1864, and the inauguration, as we have seen, took place a mere three years later. The sheer scale of accomplishment surprises still: at 62 acres, '[o]nly a twentieth of the size of the Bois de Boulogne, the park cost the city nearly twice as much'. 16 


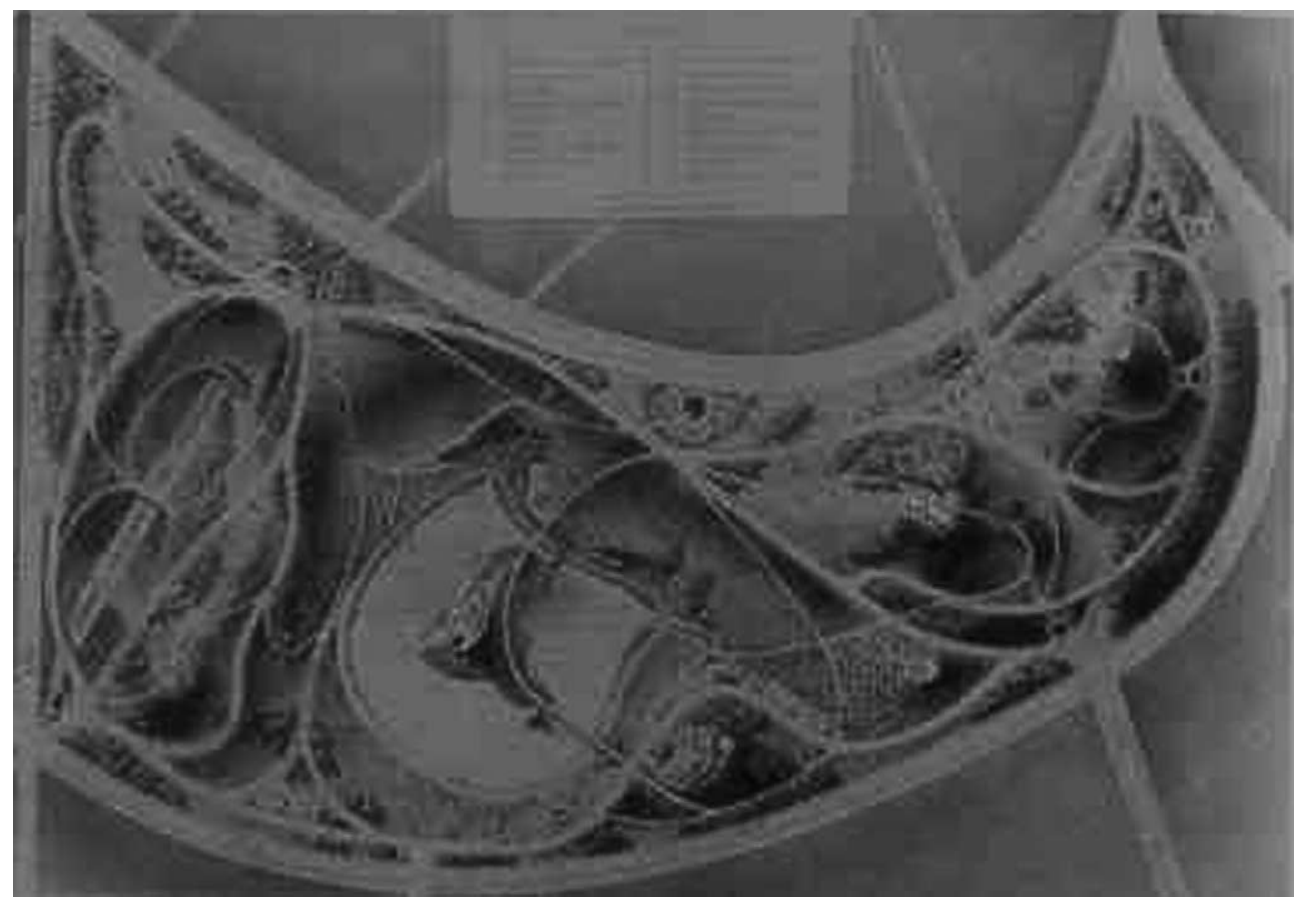

FIGURE 1 The Parc des Buttes-Chaumont in its final state. (By permission of Bibliothèque Historique de la Ville de Paris.)

The park itself was constructed by Jean Charles Adolphe Alphand (1817-91), the engineer in charge of the technical realization of so many of Haussmann's dreams and aspirations. ${ }^{17}$ Memorialized a mere seven years after his death through a monument erected at the Avenue Foch - 'Haussmann himself had to wait eighty years for the same honour $^{18}$ - Alphand is one of those figures unduly relegated to the sidelines in present-day histories of modernity. A technocrat with considerable engineering expertise, as Ingénieur des Ponts et des Chaussées he was officially put in charge of transforming Paris's bridges, streets and promenades by Haussmann in 1854, and as such he was also largely responsible for the fortification of the city during the siege of 1870. Contrary to other, more overtly political figures, Alphand survived the reign of the Emperor. He was later to be put in charge of the levelling of a small hill to the west of the Champ de Mars for the construction of the Palais de Trocadéro at the 1878 World's Fair, and become the director of the same event in 1889, finally being buried in a remarkably prominent plot in the Cimetière du Père-Lachaise. Arguably, Alphand represents the rising importance and simultaneous redefinition of the role of experts in matters technical, indicative of an overall depoliticization of public life during this period. The Parc des Buttes-Chaumont, Alphand's 'tour de force'19 as we shall see, is a particularly striking outcome of this process, not least because it deployed modern 
means to materialize, within a growing and increasingly 'machine-like' urban landscape, the aesthetic impulse so dear to the Romantics' critique of modernity. ${ }^{20}$

When first contemplated as a site for a future park, the area that was to become the Parc des Buttes-Chaumont had little to recommend it as an obvious or 'natural' choice for such a purpose. The name it then bore - Mont chauve, meaning 'bald mount' - is indicative. ${ }^{21}$ Indeed, the absence of water and anything green in what was a gypsumand-limestone environment was compounded by a series of historical presences that must have weighed heavily on the minds of those living in the area. Until their recent incorporation into Paris proper, the area was directly adjacent to the ancient gallows operative, with interruptions, from 1233 until 1792. Clearly visible on a number of ancient maps ${ }^{22}$ as the gibets de Montfaucon, these gallows were capable of executing up to 80 condemned men and women simultaneously - only to let their bodies hang until disintegration had run its natural cause. So prominently was this site ingrained into the collective psyche of Paris that Théophile Gautier, the famous nineteenth-century critic and aesthete, saw 'Babylon' - his chosen expression for Paris - being devoured by the rats of Montfaucon. ${ }^{23}$ Until 1848 the area commonly referred to as the Buttes was also one of the depositories of the city's sanitary sewage. With Haussmann's alteration of Paris, and the associated boom in the construction economy, this function was supplanted by the extension of existing but, till then, small-scale quarries ('Carrières du Centre' and the 'Plâtrière Amérique', named after the urban quarter in which they were located). ${ }^{24}$ This use of urban geology brought too the presence of 'unruly elements', those who sought refuge in caves and tunnels and who added to a perception of danger and the eerie quality of the area. ${ }^{25}$ It comes as no surprise, then, that most of the pre-Haussmannian maps of Paris strategically place their index somewhere or another in close proximity to the area that was to become the Parc des Buttes-Chaumont.

In all of this it is imperative to remember that the adjacent communes of La Villette and Belleville were incorporated into the city of Paris only in $1860 .^{26}$ Any analysis of nineteenth-century maps of Paris (see Figure 2) clearly conveys the impression of a city engulfing the area that is the Buttes-Chaumont, spilling over its previous ramparts. By 1862, the space between the two villages has been all but filled, separated only by the 'empty' space that is the Buttes-Chaumont, which increasingly is seen as a dangerous void, a 'desert'. 27 Small wonder, then, that although we can document some 85 expropriations necessary for the construction of the park, relatively few buildings mostly in the south-eastern corner of the area - needed to be destroyed to clear space for the roads bordering upon the park. ${ }^{28}$

Occupying these newly created spaces at the now incorporated periphery of Paris were those segments of the population that were no longer able to afford the everincreasing rents of the centre, as well as newly migrant labour from the countryside and from abroad. The area surrounding the Buttes in particular appears to have attracted German-speaking surplus labour, and became the neighbourhood 'from [w]here are coming out those swarms of sweepers cleaning up the streets of Paris'. ${ }^{29}$ With this in mind, the decision to centralize most of the slaughterhouses of Paris in the abattoirs of La Villette - which opened four months before, and a mere 600 metres to the north of, 

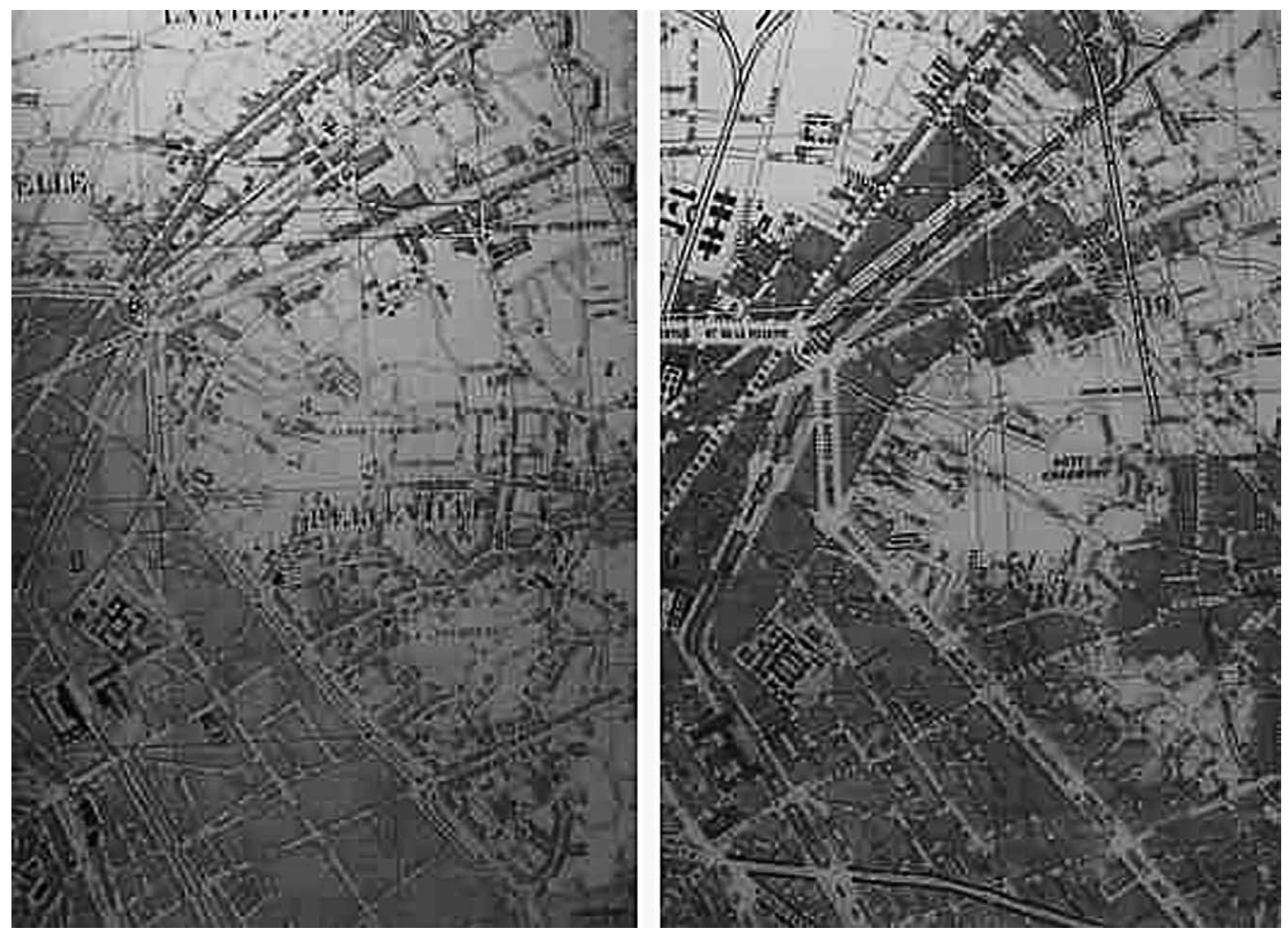

FIGURE 2 Belleville (left) 1842, (right (1862). (By permission of Bibliothèque Historique de la Ville de Paris.) 
the Parc des Buttes-Chaumont - appears to represent a more 'site-based' choice than the construction of the park itself. However, it was precisely the desire to counterbalance these histories, and to eliminate their influence on the spread of goods and capital, that made the choice of the Buttes for the construction of a park such a compelling and rational one. Before we can investigate the concrete workings of these motifs more fully, however, we need to place the Parc des Buttes-Chaumont within a more particular context: the history of public gardens and 'green' spaces in France.

\section{Constructing nature, reconfiguring people}

The Parc des Buttes-Chaumont engages with a long tradition of public parks in France and in the west more generally. ${ }^{30}$ At its most basic, it forms part of the nineteenthcentury critique of symmetrically organized gardens - embodied in France in the parks of the Ancien Regime and of André Le Nôtre in particular - through the incorporation of the Victorian model of urban 'landscape' gardens, or public parks, into the French canon from the 1830 s onward. ${ }^{31}$ Where the former, exemplified within the Parisian context by the Jardin des Tuileries (Figure 3), combined structural rigidity with a love for ornament, the latter sought to imitate nature as closely as possible. Where the former appreciated 'green' spaces primarily for their ability to embellish, the latter saw fit to interpret them in functional terms.

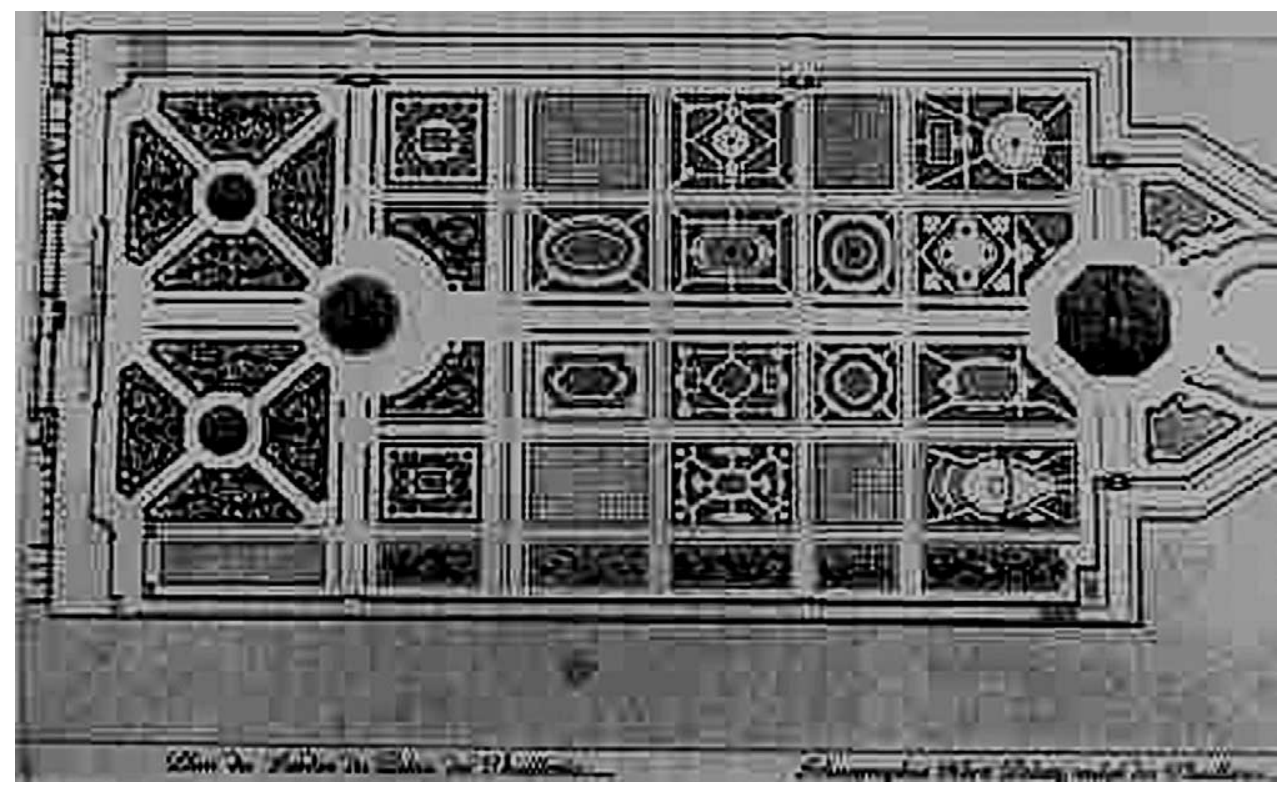

FIGURE 3 Layout of the Jardins des Tuileries, c. 1660. (By permission of Bibliothèque Historique de la Ville de Paris.) 
Technological labour, I shall argue, played a crucial role in harmonizing these two elements of the critique of symmetrical gardens - and thus was centrally involved in the shaping of a particularly 'French' path into the reconciliation of 'nature' with 'culture'. Napoleon's love of all things British, and of English gardens in particular, ${ }^{32}$ helped to facilitate the design of the Second Empire parks of Paris, but the trend towards the creation of more 'natural' urban and 'green' environments was not restricted to the French capital. Nor were the parks the only enduring legacy of the Second Empire within the French capital, as the 'green' transformation of the ChampsElysées into an organized leisure space under J.-I. Hittorf during the 1830s accommodating inter alia one of the first Panoramas in Paris - demonstrates. ${ }^{33}$

As such, this development was part of a wider transformation in society at large, and reflects the rise of an increasingly leisure-conscious bourgeoisie in the move away from the use of parks for representational purposes to a more inclusive and (crucially) edifying purpose. ${ }^{34}$ In the ideologically charged words of a contemporary surveyor of the Parc des Buttes-Chaumont: 'Liberty for all peoples under the sun has settled many social problems. ${ }^{35}$

As recent writings have taught us, there is nothing accidental about these aspects of garden designs in the nineteenth century. On the contrary, the deployment of nature as a pedagogical vehicle aimed at undermining class conflicts went hand in hand with a nominally 'progressive' conceptualization of the relationship between nature and culture. As Alphand himself noted: 'It is imperative to listen to nature, to consult it and thus to be its courtesan, not its master'. ${ }^{36}$

In the context of Paris, the park thus becomes a habitual counter-space to the guinguettes or cabarets with their morally suspect qualities. It operates as a 'moral landscape', ${ }^{37}$ in forms ranging from the ideological desire that the dangerous classes should learn from nature while being provided with 'fresh air', to direct indoctrination through the use of the park as a political theatre, ${ }^{38}$ to the mundane if important creation of a space that could shape new identities for a newly annexed population. Improving the living conditions of those living in proximity to the Buttes was thus as important as improving the populace as such. ${ }^{39}$ Crucially, this 'moral landscape' did not require the kind of top-down legislation and normative meddling with deviant forms of behaviour that had characterized interventions in sexual forms of immorality and the spaces in which they were practiced; ${ }^{40}$ rather, the design of the Buttes subtly encourages those stereotypical forms of behaviour so beloved by the bourgeosie. ${ }^{41}$ Chief amongst these was perhaps the act of 'strolling' through a landscape at once non-threatening and full of contrasts, which could thus be argued to become the moral and functional counterpart to the development of the flâneur. And similarly to the flâneur, the promeneur emerges as a clearly gendered urban character: 'Around 1855, about 90\% of those frequenting the Jardin des Tuileries were reputed to be women and children'. ${ }^{2}$

However, for this development to work, one crucial aspect of the criticized ancient tradition of constructing public gardens had to be technically amplified and thereby naturalized into the landscape: the new parks had to provide visual stimuli while remaining functionally organic. Nature, in other words, had to be made naturally dramatic. In parks like the Buttes-Chaumont, nature never simply is; rather, it is a 
reinvention of itself as contrast - with culture, with symmetry, with aristocracy, with some other form of itself.

In this manner, the park marks the difference between a potentially unorganized nature and a harmonious nature where everything, including 'wilderness' or 'irregularity', has its place. In short, not only is 'the lesson of the Buttes-Chaumont ... that the only true nature is the false one' but also it is futile from now on to differentiate between what is artificial and what is not. ${ }^{43}$ The geometrical figure so centrally implicated in the Parc des Buttes-Chaumont, the ellipse, is emblematic of this organized nature. A guiding principle of the park, the ellipse represents the perfect compromise between the two conflicting goals envisaged in its construction, being at once 'natural' and technically controllable. ${ }^{44}$ As such, it became the guiding principle of all the parks erected or renovated in Paris under the Second Empire, and reigned supreme over both general park morphology and the detailed layout of paths and flower beds. Through the ellipse, the construction of parks like the Buttes-Chaumont was transformed from an act of engineering to a work of art and scenographic practice, facilitating as it did performances of landscape and environment. A walk along an elliptical path combines elements of anticipation and enticement with a pleasantly unthreatening sense of order, leading to a 'progressive' experience of landscapes. ${ }^{45}$ Tied into an elliptical discourse structured by Alphand, this is 'walking' in an everyday space where '[t]o walk is to lack a place. It is the indefinite process of being absent and in search of a proper'. ${ }^{46}$

But the Parc des Buttes-Chaumont is furthermore original in the degree to which technology is both absent and functional in its construction. Its most prominent feature, a central mountain surrounded by a lake, was not simply a remnant from previous quarrying days; it was technically transformed with the help of recently perfected concrete to appear not as the coupled product of labour that it was but as the natural landform that it was not ${ }^{47}$ (Figure 4).

The same rationale applies to the most often noted - and indeed formulaic landform in the park: a limestone cum concrete grotto with replicas of stalagmites and stalactites. The lake itself, as well as possessing an imposing waterfall ending in the aforementioned grotto, was (and continues to be) fed artificially by waters pumped to the heights of the Buttes-Chaumont from the Canal Saint-Martin in the 10th and 11th arrondissements. ${ }^{48}$ Stairways and railings throughout the park were made from standardized, reinforced concrete which sought to imitate nature. Even the early connection of this place to the emerging network of Metro lines within the French capital - the Buttes-Chaumont were linked with the Opera as early as 1911, when the construction of line 7 came to a successful conclusion - remained invisible within the confines of the park proper. The same 'invisibility' of technology and labour rendered the now derelict chemin de fer de ceinture, the Paris ring railway, organically integrated into the park, cutting through the north-eastern portion of the Buttes and at one time providing another means of accessing the area. ${ }^{49}$

However, the absence of labour and technology from the emerging landscape was not absolute but dialectically structured. Embedded within a teleological structure of sorts, technology is rendered visible, but in a form such that an implied celebration of 


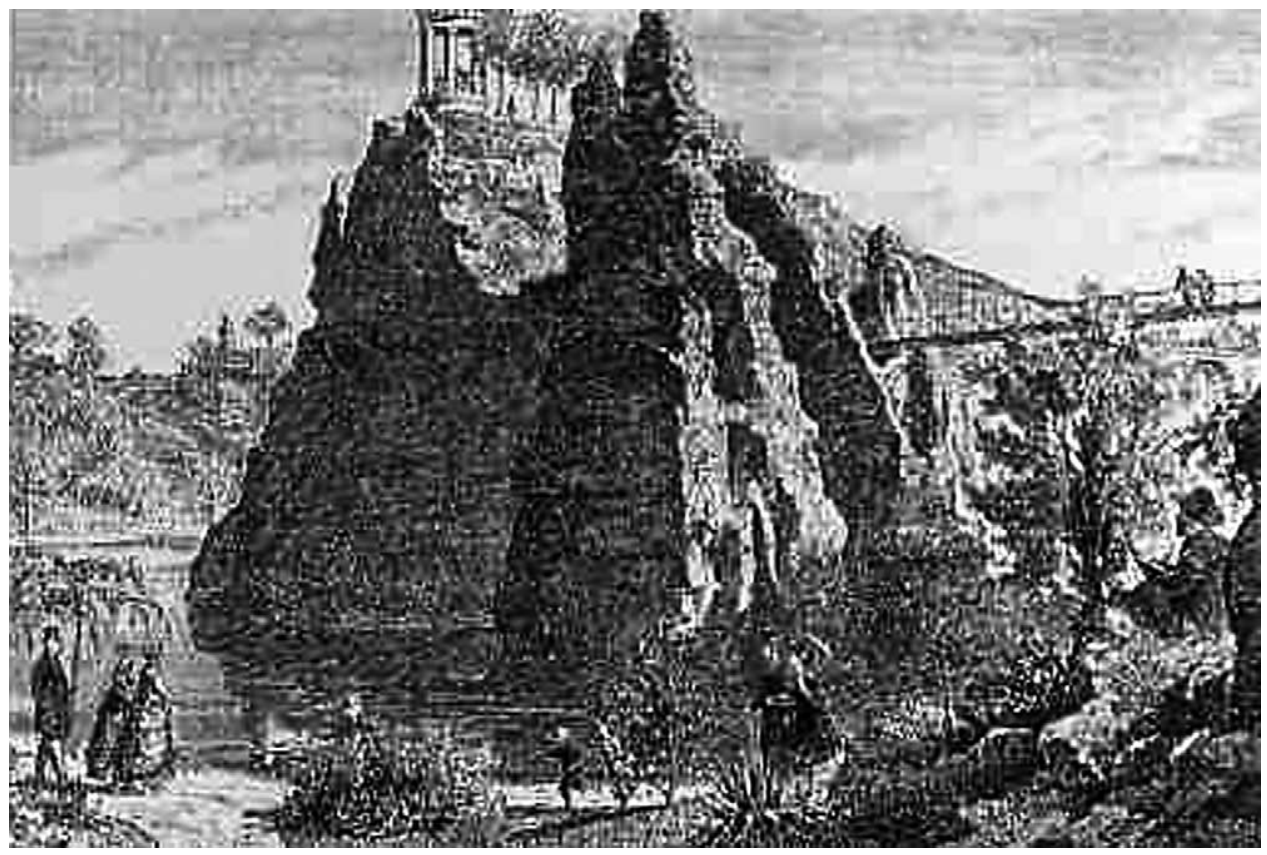

FIGURE 4 The central 'mountain' within the Parc des Buttes-Chaumont and the suicide bridge, 1880. (By permission of Bibliothèque Historique de la Ville de Paris.)

progress does not diminish the illusions of naturalness created. In the Buttes, such a spatial logic can be seen in one of the first suspension bridges in France (Figure 5). Utilizing prefabricated steel cables, and linking the central mountain across the lake to the surrounding landscape ${ }^{50}$ this suspension bridge celebrated its construction not as a product of labour but as a technological advance, an innovation. As such, the disruption of the park's illusions (of naturalness) was seamlessly replaced by another illusion (of national grandeur); crucially, both illusions require neither maintenance nor any other human input for them to become real. The same motif applies to the second, and 'merely' functional, bridge to be found in the park, which was originally constructed by Gustave Eiffel and 'where, before it was furnished with a guardrail, people who had not come with the intention of killing themselves suddenly found the abyss irresistible'. ${ }^{1}$ The 'absence' of technology is accordingly not so much an act of concealment but of acceleration; rather than being hidden, it is resolved, not unlike a Hegelian Aufhebung, into its products - which can thus celebrate both nature and human ingenuity. ${ }^{52}$

The resulting, highly constructed space thus contrasts only in appearance with the wider regulated space of Paris established under Haussmann - which not coincidentally is described by many contemporary commentators in biological metaphors. ${ }^{53}$ It is these 'naturalized' ways of conceptualizing a new park which arguably helped its conceptualization as a labour-less space. Despite the fact that the Parc des Buttes- 


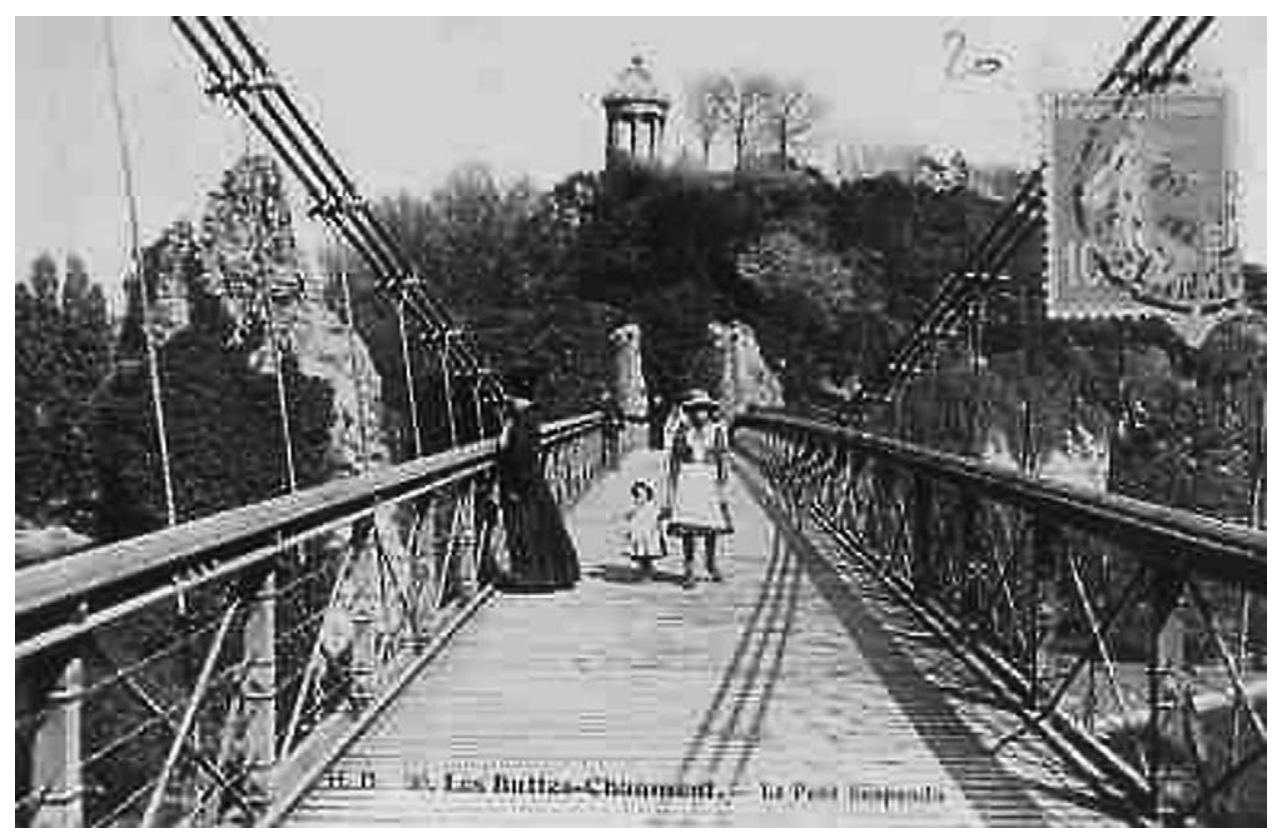

FIGURE 5 Turn-of-the century postcard of the suspension bridge. (Author's collection.)

Chaumont required 'continuous reparations', as one of Alphand's engineers stressed a mere six months after the inauguration, ${ }^{54}$ such effort never becomes labour but remains a biological necessity instead. Just as food sustains a living organism, so a park requires some kind of sustenance. Not surprisingly, contestations were therefore mainly restricted to questions of taste and style. Since too much work had gone into the construction of the park, noted one columnist at the time, 'the primitive, wild and pittoresque aspects had been sacrificed'. ${ }^{55}$ However, the majority of guidebooks remained oblivious to the many forms of labour, technology and maintenance that made the Buttes what they were: a feast for the eye and a celebration of modernity through its absence. The dual inauguration of both the park and the 1867 World's Fair thus makes sense: both events presented the products of labour as entertainment, without any detectable trace of exertion. This, I would argue, together with the linked emphasis on the spectacular character of both nature and culture, is little less than the key condition of possibility for subsequent processes of commodification. No surprise, therefore, that it is only when potential park activities have been fully commercialized that they re-enter the canon of possibilities; until that time, grass is for looking at. ${ }^{56}$

Here is the link between... metropolitan ideology and natura naturans. Nature in this sense was produced not merely as a set of objects to be admired and enjoyed, nor even a repertoire of social values. Rather, it described a structured mode of apprehension, both of the world and of oneself. ${ }^{57}$

The 'dream' or 'wish image', evoked by Walter Benjamin as a functional prerequisite for commodity capitalism to reign supreme, is but another approximation of this 
'structured mode of apprehension' which is characteristic of both nature and produced goods insofar as labour has been absented from both. Here the 'natural' aspect of something entirely constructed guarantees its visual attractiveness, in much the same way, the guidebook noted, as 'the décor of an opera' best succeeds where illusions are naturalized. ${ }^{58}$ Labour, in other words, is only successful within the urban context if and where it erases itself through its own products. ${ }^{59}$

\section{The Buttes-Chaumont and society at large}

If the history of the Parc des Buttes-Chaumont, or rather, the construction of nature in the park, allows insights into the relationship between the social and the cultural, such insights would remain sterile without a consideration of those people who have used, and continue to use, the spaces provided for them in such an elaborate manner. As such, the Buttes illuminate rather well a general change undergone by the majority of urban parks in the West. Initially a chosen space for public representations by a minority class in the early nineteenth century, urban green spaces have become a traffic-calmed enclave for children and pensioners in today's world. ${ }^{60}$ The construction of parks during the Second Empire in Paris occupies a key position in this transition: although the net result of Alphand's activities in the French capital was a loss of overall 'green' spaces, more of these were now publicly accessible in one form or another. ${ }^{61}$ Access to some form of 'nature' was hence democratized considerably.

Of the Second Empire Parisian parks, only the Bois de Boulogne attracted, and continues to attract, a public from beyond its immediate neighbourhood; 'all the other parks', as a sympathetic commentator writes some 60 years later, 'belong to their quartier' ${ }^{62}$ What this implied for the Buttes is rather obvious. Where the parks in the west of Paris were - and to some extent continue to be - parks frequented by the haute bourgeoisie, the Buttes were an enclave of the petite bourgeoisie, despite the rather expensive real estate that now border the park.

It is in this role that the park acts as one of the main protagonists in Louis Aragon's 1926 novel Le Paysan de Paris. Writing during a time strangely reminiscent of ours witness the introductory 'Preface to a modern mythology' - Aragon's protagonist finds solace in, among other places, the Parc des Buttes-Chaumont. Seeking liberation from an 'oppressive system' built upon the 'sophism of evidence', ${ }^{63}$ he turns to what is arguably one of the most constructed manifestations of modernity, but crucially does so initially at night-time, when everything is 'utterly abandoned to space'. ${ }^{64}$ The reasons for this choice are only partly explained by a certain melancholy that attaches to the materiality of a perfected, frozen nature. Writing some three generations earlier, Baudelaire had already sought to capture a similarly 'frozen' state when writing about the Buttes using the image of the 'widow' - which he contrasts with those of happy families strolling in the park. ${ }^{65}$ In Aragon's poetic language, the park furthermore becomes a nightly landscape full of simulacra, which precisely because it is modelled upon repetition can liberate the flânerie it invites from consciously seeking new sensations: 'Park, park and park. Here is the apartment of dreams: in a defile of 
artificial rocks, a passage at the bottom of the vale, near a brook bounding - the cascade lies ahead - to its downfall'. ${ }^{66}$ Dead nature, or rather arrested nature, is allowed to mimic its own state in the absence of labour; thrown back upon him- or herself, the stroller in the park is free to daydream and thus to transcend, rather than deny, labour as such. The reader thus encounters in Aragon's daydreams another, decidedly private, Parc des Buttes-Chaumont. Escaping the dichotomy between private and public spaces, which itself developed as an accompaniment to, and functional element of, modernity, ${ }^{67}$ Aragon's protagonist is free to be distracted by surreal and 'narcotic images', each of which, 'whenever it strikes, forces you to revise the entire universe':

Splendid ravages: the principle of utility will become foreign to all who practice this superior vice. For them the mind will at last cease to be 'applied'. They will see its limits recede; they will make whatever on earth is ardent and unsatisfied partake in this inebriation. ${ }^{68}$

In other words, even an ordered space such as the Parc des Buttes-Chaumont functions in a heterotopic manner, if only by encouraging daydreaming and other forms of 'absenting' from bourgeois norms. One can still detect these qualities embedded in the Parc des Buttes-Chaumont today. A 'phantasmagoric landscape, 69 which needs to be appreciated through the eyes of a child to reveal its labyrinthine qualities, the park is both more and less than we can apprehend.

What can we learn from the construction, and subsequent uses, of a space like the Parc des Buttes-Chaumont? The fact that, like other human constructs, the park partakes in, as well as alters, the social and cultural context of the Second Empire is itself almost a truism; more interesting by far is the attempt to render the park contemporary, to read it as part of an ongoing, partly complex, partly straightforward, process of modernization of the material urban environment. The fact that today the Parc des ButtesChaumont is used largely for recreational sports like jogging or Tai Chi, for instance, does not just reflect a different appreciation of urban parks; it is also indicative of a changing social structure which now surrounds the park.

Just as interesting, however, are developments nearby. The redesignation of what used to be the slaughterhouses or abattoirs of La Vilette first as the new central markets for the city of Paris - replacing the demolished Les Halles in the 1st arrondissement - and, since the early 1980s, as a new Parc de la Vilette, is indicative in more than one respect. Once again the city of Paris turned an industrial left-over space into a park for the education and amusement of the people of Paris; once again this creation of a park formed part of a re-evaluation of peripheral spaces within Paris (a process that has also included the Parc André Citroën in the 15th, the makeover of Bercy in the 12th and the Rive Gauche project in the 13th arrondissement); and once again a park reflected its own period, this time through an attempted deconstruction of many of the formulaic elements so prevalent within nineteenth-century parks. B. Tschumi's folies - empty, colourful cages spattered across the Parc de la Vilette as conditions of possibility that aspire not to prescribe - thus reinscribe into another historical landscape the same structural logic that reigned supreme in the Parc des Buttes-Chaumont. Like the crowning folie of the Buttes, a replica of the Temple of 


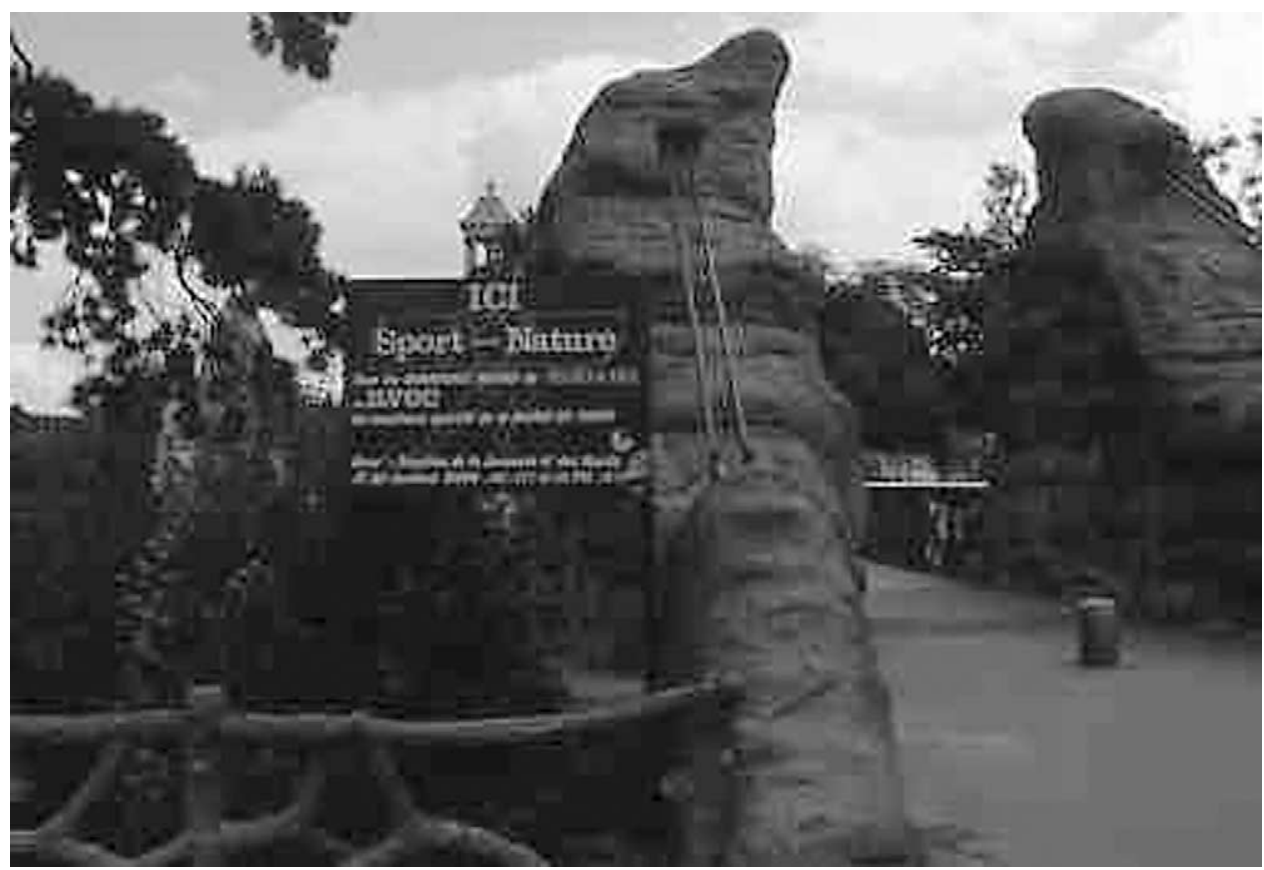

FIGURE 6 Present-day use of the Parc des Buttes-Chaumont. (Author's photograph.)

the Sibyl at Tivoli, Tschumi's empty folies are but quotes, some form of 'nature' reproduced, if now with a postmodern twist: what purports to be empty should easily be adaptable to anything. Similarly fitting is the fact that the Parc de la Villette houses pure technology, simply historicized in the form of a newly constructed museum of science, the Cité des Sciences et Industries, which is placed alongside a newly centralized college of music. How better to symbolize the changing nature of 'modernity' than to compare the hidden with the overt celebration of technology at the two parks? ${ }^{70}$

The Parc des Buttes-Chaumont, despite the overt lack of openly commodified nature, in fact resembles its commodified counterpart in the simultaneously developing grands magasins or department stores of central Paris. Both render invisible what supports them: labour and technology. ${ }^{71}$ Both spaces embody the promise of leisure and pleasure untainted by the myriad forms of labour that are required for their construction and maintenance. In this obviously false and ideologically charged illusion, the Buttes do not differ fundamentally from older parks. Rather, the novelty resides in how technology becomes centrally involved in the ideologically constructed dissolving of labour into nature, where the invisibility of the former becomes a factor conditioning the social uses of the latter. It may be helpful in this context to remember the eighteenth century differentiation between 'first' and 'second' nature invented by the French scientist Count Buffon. ${ }^{72}$ In this tradition, the transition towards 'second' 
nature marks the space of labour only insofar as it is capable of naturalizing social meanings. By the nineteenth century, the most potent of mechanisms implicated in this process was the commodification of ever larger parts of an increasingly bourgeois everyday life. Crucially, this transition did not merely affect both 'nature' and 'culture', but cut a clear passage within the ongoing history of modernity. It is in this form that the present essay adopts as a final vanishing point the notion of entertainment. For the defining hallmark of entertainment since the days of the construction of the Buttes has been the implication of technology in the creation of labour-less illusions. Cinema, Nike and Disney World thus become the twenty-first-century extensions of the act of 'strolling' we saw emerge in the technologically created space that was - and still is the Parc des Buttes-Chaumont, hiding their conditions of possibility rather effectively indeed. The landscapes of naturalized entertainment, of simulated nature, ${ }^{73}$ are landscapes of consumption. Whether they are consumed as reality or as simulacra, what matters is the functional masking of their fabricated nature. Unmasking this labour, making it visible, is one of the crucial tasks in studies of nature, technology and the modern city.

\section{Notes}

${ }^{1}$ See e.g. D. Nicholson-Lord, The greening of cities (London, Routledge, 1987), and, more recently, V. Papanek, The green imperative: ecology and ethics in design and architecture (London, Thames \& Hudson, 1995).

2 Apart from the magisterial W. Cronon, Nature's metropolis: Chicago and the great West (New York, Norton, 1991), three key works come to mind in this context: C. Galen, The politics of park design (Cambridge, MA, MIT Press, 1984), N. Green, The spectacle of nature: landscape and bourgeois culture in nineteenth-century France (Manchester, Manchester University Press, 1990), and M. Gandy, Concrete and clay: reworking nature in New York City (Cambridge, MA, MIT Press, 2002).

3 See e.g. E. Swyngedouw, 'Modernity and hybridity: nature, regeneracionismo, and the production of the Spanish waterscape, 1890-1930', Annals of the Association of American Geographers 89 (1999), pp. 443-65.

${ }^{4} \mathrm{~J}$. Barrell, The dark side of the landscape: the rural poor in English painting 1730-1840 (Cambridge, Cambridge University Press, 1980); D. Cosgrove, Social formation and symbolic landscape (Totowa, NJ, Barnes \& Noble, 1984).

5 See esp. M. Fitzsimmons, 'The matter of nature', Antipode 21 (1989), pp. 106-20; L. Kong and B. Yeoh, 'Social construction of nature in urban Singapore', Southeastern Asian studies 34 (1996), pp. 402-23; N. Castree, 'The nature of produced nature', Antipode 27 (1995), pp. 1248.

${ }^{6}$ D. Mitchell in his 'Dead labour and the political economy of landscape: California living, California dying', in K. Anderson et al., eds, Handbook of cultural geography (London, Sage, 2003), pp. 233-48.

7 D. Demeritt, 'Being constructive about nature', in N. Castree and B. Braun, eds, Social nature: theory, practice and politics (Oxford, Blackwell, 2001), pp. 22-40, esp. pp. 29-31.

8 On the question of what to include amongst those materialities that appear in an urban context, see the actor network theory-inspired comment by S. Hinchliffe et al., 'Urban wild 
things: a cosmopolitical experiment', Environment and planning D: society and space 23 (2005), pp. 643-58.

9 B. Debarbieux, 'The mountain in the city: social uses and transformations of a natural landform in urban space', Ecumene 5 (1998), pp. 399-431.

${ }^{10}$ Parc des Buttes Saint-Chaumont, Guide du promeneur (Paris, Librairie Internationale, 1867), pp. 9-10, 25. Translations from the French, unless otherwise indicated, are by me.

11 Remarkably, few titles exist that contextualize the Buttes-Chaumont within the context of Haussmann's transformation of Paris. Of these, I found the following titles of particular interest: A. Grumbach, 'The promenades of Paris', Oppositions 8 (1977), pp. 51-67; K. Oxenius, Vom Promenieren zum Spazieren. Zur Kulturgeschichte des Pariser Parks (Tübingen, Untersuchungen des Ludwig-Uhland-Instituts, 1992); and H. M. Schenker, 'Parks and politics during the Second Empire in Paris', Landscape journal 14 (1995), pp. 201-19.

12 The indispensable entry point to the transformation of Paris during the Second Empire is still D. Pinkney, Napoleon III and the Rebuilding of Paris (Princeton, NJ, Princeton University Press, 1958), while the most concise access is formulated in D. Jordan, 'Baron Haussmann and modern Paris', American scholar 61 (1992), pp. 99-108. See also H. Malet, Le Baron Haussmann et la rénovation de Paris (Paris, Les Éditions Municipales, 1973); J. Gaillard, Paris, la ville, 1852-1870: l'urbanisme parisien à l'heure d'Haussmann (Paris, Champion, 1977); D. Harvey, 'Paris, 1850-1870', in Consciousness and the urban experiment (Oxford, Blackwell, 1985); M. Gandy, 'The Paris sewers and the rationalisation of urban space', Transactions of the Institute of British Geographers 24 (1999), pp. 23-44; J. des Cars and P. Pinon, Paris: Haussmann (Paris, Picard, 1991); P. Lavedan, Histoire de l'urbanisme à Paris (Paris, Hachette, 1975); and A. Sutcliffe, The autumn of central Paris: the defeat of town planning, 1850-1970 (London, Arnold, 1973).

13 Schenker, 'Parks and politics during the Second Empire in Paris', who notes that '[o]n the plan of Paris as reconstructed during the Second Empire, the parks occurred in a balanced spatial configuration' (p. 207).

${ }^{14}$ See esp. D. Harvey, The urbanisation of capital (London, Blackwell, 1985), and Gaillard, Paris.

15 Which is not to say that private interests were absent from considerations such as those that gave birth to parks like the Buttes-Chaumont, as testified by the increase in land value in what was basically a speculation desert.

16 F. Frascina et al., Modernity and modernism (New Haven, CT, Yale University Press, 1993), p. 104. Incidentally, it was less the amount of money spent on the construction of the park that impressed contemporary commentators than the speed with which the 'bare hills have been covered with soil for growth': M. Petit, 'Les Buttes-Chaumont', Le Magasin pittoresque 51 (1883), p. 92.

${ }^{17}$ In this, Alphand was not alone: Haussmann surrounded himself with technocrats like Eugène Belgrand, Jacques Hittorf and Émile Deschamps throughout his reign as Prefect; see B. Rouleau, Paris: histoire d'un espace (Paris, Seuil, 1997), esp. p. 355.

18 G. Poisson, 'Alphand', in J. Tulard, ed., Dictionnaire du Second Empire (Paris, Fayard, 1995), 9. 55 .

19 George F. Chadwick, The town and the park: public landscape in the nineteenth and twentieth centuries (New York, Praeger, 1966), p. 158.

20 Alphand's memorial on the Avenue Foch reinforces this view of the role of experts in modern societies. Surrounded by clearly subordinate colleagues, Alphand here is a suitable two steps removed from a bas-relief of workers. See J. Hargrove, Les statues de Paris (Paris, Albin Michel, 1989), p. 164, who notes the wide contributions of the Parisian populace to the 
subscription of the monument. The speeches at the inauguration furthermore emphasize the apparently 'democratic' qualities embodied by the expert. See G. Larroumet, Discours à l'occasion de l'inauguration du monument élevé à la mémoire de J.-C.-A. Alphand le 14 décembre 1899 (Paris, Institut de France, 1899). In many ways Alphand thus occupies in French society a role akin to the one occupied by F. L. Olmsted across the Atlantic; see Debarbieux, 'The mountain in the city', p. 410.

21 As a number of memos from within Alphand's staff demonstrate, the 'poor ground' present at the site made many doubt the feasibility of the project; cf. Archives de Paris [AdP], VO (n.c.) 291.

22 Examples include Truschet and Hoyeau's 'Plan de Bâle' of 1552, Pigafetta's 'Plan de Parigi' of 1591 or the 1609 plan of Paris by Vassalieu (dit Nicolay).

23 As referenced in W. Benjamin, Das Passagen-Werk (Frankfurt am Main, Suhrkamp, 1982) C 4a, 3.

${ }^{24}$ Smaller segments of these quarries were reopened in 1870 during the siege of Paris; see E. Chantard, Goualantes de La Villette et d'ailleurs (Paris, Seheur, 1929), p. 29.

25 See esp. C. Prendergast, Paris and the nineteenth century (Oxford, Blackwell, 1992), pp. 7778.

26 Alone among the villages newly incorporated into the city of Paris, Belleville was literally segmented into oblivion by the redrawing of boundaries in 1860; see AdP, D.30.Z, Coll. E. Saffroy.

${ }^{27}$ Internal memo within Alphand's office, 16 Nov. 1861, AdP, VO (n.c.) 291. Both Haussmann and Alphand clearly perceived the site to be a flaw within the context of their plans for Paris; see Georges Engène Haussmann, Mémoires (3 vols, Paris, Victor-Havard, 1890-93), vol. 3, p. 234; J.-C. Adolphe Alphand, Les promenades de Paris (2 vols, Paris, Rothschild, 1867-73), p. 203.

28 The quarries in turn had already been bought by the city of Paris in 1862, after a new law had prohibited any underground exploitation within the (altered) bounds of Paris after 1860; see the files contained in 'Expropriations 610' at the Bibliothèque Historique de la Ville de Paris [BHVP] and AdP, VN4/186.

${ }^{29}$ G. Boué, The squares and gardens of Paris: the Buttes-Chaumont (Paris, Hennyer, n.d.), p. 15. The presence of a 'German' element within the city of Paris was to be officially erased after the Franco-Prussian war of 1870, when the main artery just to the north of the park, the rue d'Allemagne, was renamed Avenue Jean Jaurès.

30 The history of urban public parks has been analysed most fruitfully in F. Debié, Jardins de capitales: une géographie des parcs et jardins publics de Paris, Londres, Vienne et Berlin (Paris, CNRS, 1992). See also D. Le Dantec and J. Pierre, Reading the French garden: story and history (Cambridge, MA, MIT Press, 1990).

31 Chadwick, The town and the park. We need to note that this renaissance in the construction of urban parks was not restricted to France, but took place almost everywhere in Western, industrialized societies, witness the simultaneous construction of Central Park in New York; see L. Wyman, 'Landscape architecture: the dialogue between society and ideological vision', Architecture and urbanism (1996), 312 pp. 122-27. A remarkable analysis of the rise of the 'pleasure garden' can be found in Miles Ogborn, Spaces of modernity London's geographies 1680-1780 (New York, Guilford, 1998), esp. pp. 116-57.

32 See esp. Haussmann, Mémoires, vol. 1, p. 240.

33 See T. von Joest, 'Haussmann's Paris: a green metropolis?', in M. Mosser and G. Teyssot, eds, The history of garden design: the Western tradition from the Renaissance to the present day (London, Thames \& Hudson, 1991), pp. 387-98. The reference to the Panorama can be found 
in U. Westfehling, 'Le Panorama', in Hittorf, un architecte du XIXème (Paris, Musée Carnavalet, 1986), p. 189.

34 'Inclusive' in the present context does not merely signal the gradual access of more and different classes into the space that is the park; it also implies the admission of different age groups such as (crucially) children. On the changing social role of parks in Paris, see M. Conan and I. Marghieri, 'Figures on the grass: the public gardens of Paris', Landscape 31 (1991), pp. 29-35. Prendergast ties the rising importance of public greens during the Second Empire into a general trend of bringing 'the pastoral' and 'the urban' into a closer contact, a fashion he sees illustrated inter alia by many Impressionist paintings of the period: Paris and the nineteenth century, p. 166.

35 Boué, The squares and gardens of Paris: the Buttes-Chaumont, p. 1. The term 'moral geographies' was popularized particularly in the work of F. Driver; see his 'Moral geography: social science and the urban environment in nineteenth century England', Transactions of the Institute of British Geographers 13 (1988), pp. 275-87. The 'democratic' aspects of public gardens are further analysed in Prendergast, Paris and the nineteenth century, pp. 168-70.

36 Alphand, as quoted in Marie-Blanche d'Arneville's article on gardens ('Jardins') in Tulard, Dictionnaire, p. 668. The progressive character of this early 'environmentalism' has been studied in Green, The spectacle of nature, who notes that both Haussmann and Alphand cited the need for fresh air and public bealth benefits among the justifications for constructing public gardens during the Second Empire.

37 Debié, Jardins des capitales p. 180. The nexus between habitus and 'moral' qualities embedded in particular landscapes has been analysed for contemporary spaces in G. Setten, 'The habitus, the rule and the moral landscape', Cultural geographies 11 (2004), pp. 389-415.

38 On the latter aspects, see J.-E. Bayard, 'Guignol et la guerre', Les Annales politiques et littéraires (1928) 1821, p. 414.

39 See D. Matless, 'Moral geographies of the English landscape', Landscape research 22 (1997), pp. $141-55$.

40 See P. Howell, 'A private contagious diseases act: prostitution and public space in Victorian Cambridge', Journal of historical geography 26 (2000), pp. 376-402.

41 This encouragement thus arguably becomes akin to the moral guidance provided in a more mediated environment by late nineteenth-century melodramas, with their similar insistence on dramatic contrasts and moral choices. See H. M. Schenker, 'Central Park and the melodramatic imagination', Journal of urban bistory 29 (2003), pp. 375-93.

42 Oxenius, Vom Promenieren, 86. Indicatively for the history of the Buttes-Chaumont, Baudelaire himself planned to include a prose poem entitled 'Du haut des Buttes-Chaumont' in his Le Spleen de Paris. On Baudelaire and Paris, see D. Gregory, Geographical imaginations (Oxford, Blackwell, 1994), esp. pp. 221-23.

43 Grumbach, 'The promenades of Paris', p. 66.

${ }^{44}$ On the figure of the ellipse, see esp. C. Asendorf, 'Parabeln und Hyperbeln. Über die Kodierung von Kurven', in C. Hoffmann and P. Berz eds, Über Schall. Ernst Mach und Peter Salchers Geschoßfotographien (Göttingen, Wallstein, 2001).

45 Debarbieux, 'The mountain in the city', p. 413.

46 M. de Certeau, The practice of everyday life, trans. S. Rendall (Berkeley, University of California Press, 1984), p. 103.

47 Coincidence or not, it is worthwhile to recall not only that the new technique of reinforced concrete originated in a patent granted to the Frenchman Joseph Monier in the same year, 1867 , but that the patent in question was awarded for the construction of a flower tub 
produced by employing the new method; see W. König and W. Weber, Netzwerke, Stahl und Strom. Propyläen Technikgeschichte, vol. 4 (Berlin, Ullstein, 1997), esp. pp. 290-92.

48 A most thought-provoking study of the role of water in urban environments is I. Illich, $\mathrm{H}_{2} \mathrm{O}$ and the waters of forgetfulness (London, Marion Boyars, 1986).

49 This line of the Metro is today known as the relatively short branch line '7bis'; see A. Bindi and D. Lefeuvre, Le Métro de Paris (Rennes, Éditions Ouest-France, 1990), esp. p. 20. The connection between an older Parisian underground made of 'grottoes' and 'catacombs' and the Metro - where the latter de-demonizes the former - has been drawn by Benjamin, Das Passagen-Werk, C 2, 1; importantly at the Buttes-Chaumont, the absence of technological support in the perfectionionizing of 'nature' makes this link an even more engaging one. On the chemin de fer de ceinture, see M.-B. d'Arneville, 'Jardins', in Tulard, Dictionnaire, esp. p. 668.

50 Y. Lefresne, 'La construction de la passerelle suspendue du Parc des Buttes-Chaumont à Paris', Travaux 482 (1975), pp. 59-61.

51 Aragon, Le paysan de Paris, p. 112. The history of this particular bridge is documented in many official documents preserved in the AdP, Perotin/10653/95.

52 This motif is arguably one of the defining characteristics of modernity at large: a complex interweaving of 'presences' and 'absences' which can only ever be rendered as a 'now' through the use of ideologies. See U. Strohmayer, 'Technology, modernity and the restructuring of the present in historical geographies', Geografiska Annaler 79B (1997), pp. 155-69.

53 See V. Fournel, Paris nouveau et Paris futur (Paris, Lecoffe, 1865), who likens boulevards to 'arteries' (p. 12) and compares an ancient Paris that is no more to an old forest that has been put to use (p. 13-14).

54 Report within Alphand's office, 18 Nov. 1867, AdP, V.O. (n.c.), 292. See also AdP, Perotin/ 10653/110.

55 A. Joanne, quoted in E. Jacomin, 'Si le Parc des Buttes-Chaumont m'était conté ...', 75-20 (1984), p. 32; for an early if slightly eccentric critique, see also W. Robinson, The parks, promenades and gardens of Paris (London, John Murray, 1869).

56 On the 'spectacular' nature of public gardens, see Green, The spectacle of nature; the complex, and often contradictory, involvement of 'spectacular' elements on the sites of various industrial fairs has been analysed in A. Pred, 'Spectacular articulations of modernity: the Stockholm Exhibition of 1897', Geografiska Annaler 73B (1897), pp. 45-84, U. Strohmayer, 'Pictorial symbolism in the age of innocence: material geographies at the Paris World's Fair of 1937', Ecumene 3 (1996), pp. 282-304, and T. Gronberg, Designs on modernity: exhibiting the city in 1920s Paris (Manchester, Manchester University Press, 1998). The 'visual' aspects of the park, as M. Marceca noted, were not restricted to 'natural' elements but included the city as well, which revealed itself to the visitor - like the image of a modern panorama with modelled roads, locomotives and smoking chimneys' - after having climbed one of the numerous grass mounts: 'Reservoir, circulation, residue: J.C.A. Alphand, technological beauty and the green city', Lotus 30 (1981), p. 63.

57 Green, The spectacle of nature, p. 71.

58 Parc des Buttes Saint-Chaumont, p. 38. Benjamin's evocation of 'dreams' and 'images' appears in his Passagen-Werk; see S. Buck-Morss, The dialectics of seeing (Cambridge, MA, MIT Press, 1989), esp. pp. 114-19. The 'picturesque' as embodied in parks is of course intricately linked to the display of artificially designed landscapes in panoramas and dioramas, both of which thrived before photography became a more widespread substitute in the procuration of images: see Green, The spectacle of nature, esp. p. 95. Writes L. Wyman: 'At the ButtesChaumont, we do not find rural nature in the city but a form of "hyper park", arguably a 
forerunner to the contemporary theme park': 'Landscape architecture: the dialogue between society and ideological vision', Architecture and urbanism 312 (1996), p. 123.

59 A similar argument has been presented by Mitchell in 'Dead labour and the political economy of landscape'.

${ }^{60}$ Within the Parisian context, this transition has been captured remarkably well in Oxenius, Vom Promenieren zum Spazieren.

61 This at least is the résumé offered by Georges Poisson in his article on Alphand in Tulard, Dictionnaire.

62 P. d'Espezel, 'Sur les Buttes-Chaumont', Revue de Paris 46 (1939), p. 475. This impression is further accentuated by the omission of any mention of the Parc des Buttes-Chaumont from the majority of Parisian guidebooks, many of which were explicitly updated for the 1867 World's Fair: see E. Alonnier and J. Décembre, Les merveilles du nouveau Paris (Paris, BernardinBéchet, 1867).

63 Aragon, Le Paysan de Paris, p. 1.

${ }^{64}$ Ibid. p. 112.

65 As discussed in Prendergast, Paris and the nineteenth century, p. 179.

66 Aragon, Le Paysan de Paris, p. 147.

67 On the historical and modern nature of the relationship between private and public spaces, see in particular L. Bondi and M. Domosh, 'On the contours of public space: a tale of three women', Antipode 30 (1998), pp. 270-89.

68 Aragon, Le Paysan de Paris, pp. 52-53. Benjamin's assessment of surrealism is particularly apt here: 'Everything with which it came into contact was integrated. Life only seemed worth living where the threshold between waking and sleeping was worn away in everyone as by the steps of multitudinous images flooding back and forth, language only seemed itself where sound and image, image and sound interpenetrated with automatic precision and such felicity that no chink was left for the penny-in-the-slot called "meaning": 'Surrealism: the last snapshot of the European intelligentsia', in One-way street, trans. E. Jephcott and K. Shorter (London, Verso, 1985), p. 226.

69 F. Combes, 'Le voyageur du metro aérien: expédition aux Buttes Chaumont', Europe 69 (1991), p. 157. 'The phantasmagoria of capitalist culture blossoms most spectacularly at the World's Fair of 1867': Benjamin, 'Paris', p. 176.

${ }^{70}$ E.K. Mayer, 'The public park as avant-garde (landscape) architecture: a comparative interpretation of two Parisian parks, Parc de la Villette (1983-1990) and Parc des ButtesChaumont (1864-1867)', Landscape journal 10 (1991), pp. 16-26.

71 This is not to deny the fact that 'nature' had been commercialized within the context of formal gardens or parks for some time already prior to the construction of the Buttes-Chaumont. As C. Mukerji reminds us, through partaking in the plant trade and by initiating at least partly the culture of collecting since the seventeenth century, the design of nature had for some time already been implicated in processes through which capitalism gained social value. However, the 'veiling' of labour takes on a new and more central meaning once it is facilitated through mass production technologies: it becomes both a spectacle and an achievement at the same time. See C. Mukerji, 'Reading and writing with nature: a materialist approach to French formal gardens', in J. Brewer and R. Porter, eds, Consumption and the world of goods (London, Routledge, 1993), pp. 439-61.

72 My thanks to Tim Cresswell, who provided the initial sparks for what follows during a lengthy walk through the Parc des Buttes-Chaumont. The most influential discussion of Buffon can be found in N. Smith, Uneven development (Oxford, Blackwell, 1984), pp. 46-55.

73 See J. S. Light, 'The changing nature of nature', Ecumene 4 (1997), pp. 181-95, esp. p. 183. 